\title{
Analisis Usabilitas Sistem Informasi Perpustakaan (Sipus) Integrasi UGM***
}

\author{
Ikhwan Arif*, \\ email: iwanarif@ugm.ac.id \\ Budhi Santoso** \\ email: kangbudhi@ugm.ac.id
}

\begin{abstract}
It is important to assess usability of Integrated Library Information System (SIPUS) at UGM in order to find out whether the system that has been developed by the Central Library of UGM is useful and accepted by user libraries spread out within the campus. There are three criteria of usability assessment based on the standard of ISO 9241-11 (1998), i.e. efficiency, effectiveness, and satisfaction. This ISO standard is used because it has a series of assessment criteria relevant with the problems of SIPUS implementation at various libraries within UGM. The study was descriptive quantitative. Data collected during the study were analyzed using statistical method and interpreted. Population of the study were the librarians at UGM. Samples consisted of 30 librarians/library staff at faculty libraries, Central Library, the library of vocational school and Jakarta Campus. The result of analysis and discussion showed that usability, effectiveness and efficiency of integrated SIPUS implementation were very high.
\end{abstract}

Keywords: usability of information system, library automation assessment; library information system *) Perpustakaan Fakultas Hukum UGM

**) Perpustakaan Fakultas Geografi UGM

***) Pemenang Hibah Penelitian Perpustakaan UGMtahun 2016

\section{A. PENDAhULUAN}

Para ahli sistem informasi sepakat bahwa prinsip utama yang dijadikan ukuran keberhasilan pengembangan sistem informasi (SI) ataupun perangkat lunak adalah usabilitas. Tingkat usabilitas akan menentukan apakah sistem informasi tersebut bermanfaat, diterima user dan bertahan lama dalam penggunaannya. Untuk itu penilaian tingkat usabilitas suatu sistem informasi penting dilakukan guna mengetahui apakah sistem yang dikembangkan tersebut telah sesuai dengan tujuan yang diharapkan oleh institusi yang menggunakannya. Sistem yang memiliki tingkat usabilitas yang tinggi akan digunakan dalam jangka waktu yang lama karena banyak orang merasakan manfaat dari sistem, sedangkan sistem yang memiliki usabilitas yang rendah pada akhirnya akan diabaikan oleh pengguna.

Menyadari perkembangan kebutuhan informasi di berbagai perpustakaan yang begitu beragam serta pentingnya integrasi sistem informasi di berbagai perpustakaan yang ada di UGM maka sejak 2013 Perpustakaan UGM mengembangkan sistem informasi perpustakaan berbasis web yang dikenal dengan nama SIPUS Integrasi. Tujuan dari dikembangkanya sistem ini adalah untuk membuat sistem informasi standar yang bisa digunakan untuk mengintegrasikan berbagai sistem informasi perpustakaan yang ada di UGM.

\section{SIPUS Integrasi}

Keberadaan SIPUS Integrasi ini sendiri bukanlah hal baru karena sejatinya sistem ini merupakan hasil pengembangan sistem dari versi sebelumnya yang telah digunakan di berbagai perpustakaan di UGM. Aplikasi SIPUS pertama kali dikembangkan pada tahun 2000 hasil kerjasama antara Perpustakaan UGM dengan beberapa mahasiswa jurusan Komputer Fakultas MIPA UGM yang magang di Perpustakaan UGM. Pengembangan Sipus selanjutnya dilakukan melalui kerjasama antara 
Perpustakaan UGM dengan perusahaan pengembang perangkat lunak Gamatechno hingga tahun 2006/2007. Hasil kerjasama ini selanjutnya menghasilkan software SIPUS versi 2, 3 dan 4. Setelah kontrak kerjasama dengan Gamatechno selesai mulai tahun 2010 Perpustakaan UGM mulai mampu untuk mengembangkan sendiri sistem informasinya dengan meneruskan generasi SIPUS yang dikenal dengan nama SIPUS Integrasi.

Sebelum menggunakan SIPUS Integrasi sebagai aplikasi standar bagi sistem informasi perpustakaan di UGM pada tahun 2012-an beberapa perpustakaan di lingkungan UGM masih menggunakan software yang berbedabeda, dan diperoleh dengan berbagai cara, baik dengan membeli atau mengembangkan sendiri maupun menggunakan software yang bersifat free lisence. Adapun software sebelum di gunakan SIPUS Integrasi adalah: SIPUS V2 \&V3, Ibra, Open Biblio, Sintesis, Rotasi, CDS/ISIS, dan lain sebagainya. Jika dibanding dengan software yang ada sebelumnya menurut pengalaman peneliti SIPUS Integrasi memiliki beberapa keunggulan antara lain adalah:

1. Sipus Integrasi memiliki kemampuan dalam menangani berbagai sistem sirkulasi buku di berbagai perpustakaan yang berbeda-beda baik dari jumlah buku yang dipinjam, jenis, waktu pinjam serta denda.

2. Sebagian data atau informasi yang ada Sipus Integrasi seperti data mahasiswa merupakan hasil unduhan yang terhubung dari sistem informasi UGM lainya seperti bagian kemahasiswaan \& akademik sehingga memudahkan perpustakaan melakukan proses aktifasi anggota perpustakaan. Hal ini dikarenakan data mahasiswa di UGM secara otomatis masuk dalam database anggota SIPUS Integrasi.

3. Statistik dan laporan dalam Sipus Integrasi lebih lengkap dan menyeluruh dari semua perpustakaan di UGM yang menggunakan sistem ini.

4. Sistem dikembangkan dan dikelola sendiri oleh staf bagian Teknologi Informasi sehingga lebih mudah dalam pengembangan dan penanganan bila terjadi permasalahan dalam operasional.

\section{Tujuan}

Melihat fakta kemampuan SIPUS Integrasi yang telah berkembang pesat sedemikian rupa tersebut maka mendorong peneliti untuk merancang penelitian untuk melihat tingkatan usabilitas SIPUS Integrasi yang telah 4 tahun lebih diimplementasikan di berbagai perpustakaan fakultas dan unit lain di UGM.

Pengukuran ini dilakukan untuk mengetahui apakah SIPUS Integrasi bermanfaat, dapat diterima oleh user dan akankah sistem ini dapat bertahan lama dalam penggunaannya. Secara teori sistem dengan tingkat usabilitas yang tinggi akan membuat sistem tersebut populer dalam waktu lama dan luas penggunaannya karena banyak orang atau institusi yang telah merasakan manfaatnya.

Penelitian ini dilakukan karena sejak implementasi integrasi sistem menggunakan SIPUS Integrasi ini belum pernah dilakukan kajian terhadap tingkat usabilitas sistem ini. Menurut Weber (1999) penilaian usabilitas sistem informasi pasca-implementasi penting dilakukan oleh organisasi yang menerapkan sistem informasi untuk melihat apakah penerapan sistem telah sesuai dengan tujuan yang diharapkan.

Guna mengukur usabilitas SIPUS Integrasi peneliti menggunakan kriteria usabilitas yang mengacu pada standar ISO 9241-11 (1998). Dalam standar ini terdapat 3 aspek pengukuran usabilitas yaitu efisiensi, efektivitas dan kepuasan. Adapun alasan digunakannya standar ini karena ISO 9241-11 memiliki seperangkat kriteria penilaian yang relevan dengan permasalahan implementasi Sipus Integrasi di berbagai perpustakaan di UGM.

\section{B. TINJAUAN PUSTAKA}

Usabilitas telah menjadi kriteria yang penting bagi pengambil keputusan pengembang perangkat lunak khususnya untuk mengukur keberhasilan sistem informasi yang dikembangkannya. Bagi sebuah organisasi kerja, sistem informasi berfungsi sebagai sarana atau alat kerja untuk membantu proses bisnis yang ada dalam rangka pencapaian tujuan organisasi melalui penyediaan informasi. Keberhasilan sebuah sistem informasi tidak hanya ditentukan oleh bagaimana sistem dapat memproses masukkan dan menghasilkan informasi dengan baik, tetapi juga bagaimana pengguna ma u men e ima dan menggunakannya, sehingga mampu mencapai tujuan organisasi. 
Penilaian terhadap SIPUS sangat penting dilakukan untuk mendapatkan hasil evaluasi dari produk yang dikembangkan oleh Perpustakaan UGM hal ini sesuai dengan pendapat Rubin dan Chisnell (2008) yang menyatakan bahwa penilaian usabilitas merupakan teknik yang digunakan untuk mengevaluasi sebuah produk. Demikian juga pendapat Weber (1999) yang menyatakan penilaian usabilitas sistem informasi pascaimplementasi penting dilakukan oleh organisasi yang menerapkan sistem informasi untuk melihat apakah penerapan sistem telah sesuai dengan tujuan yang diharapkan.

\section{Pengertian Usabilitas}

Usabilitas berasal dari bahasa Inggris yaitu usable yang berarti dapat digunakan dengan baik. Guna memberikan gambaran yang lebih detail berikut definisi usabilitas yang dikemukan oleh beberapa pakar:

1. Usabilitas adalah sebuah ukuran sebuah karakteristik yang mendeskripsikan seberapa efektif seorang pengguna dalam berinteraksi dengan suatu produk. Usabilitas juga merupakan ukuran seberapa mudah suatu produk bisa dipelajari dengan cepat dan seberapa mudah suatu produk bisa digunakan. (JeffAxup (2004)

2. Usabilitas digunakan untuk mengukur tingkat pengalaman pengguna ketika berinteraksi dengan produk sistem. Secara umum, usabilitas mengacu kepada bagaimana pengguna bisa memperlajari dan menggunakan produk untuk memperoleh tujuannya, dan seberapa puas mereka terhadap penggunaannya.( Dumas et.al(1999))

3. Usabilitas menurut ISO 9241: 11 (1998) adalah sejauh mana suatu produk dapat digunakan oleh pengguna tertentu untuk mencapai target yang ditetapkan dengan standar efektivitas, efisiensi dan kepuasan penggunaan dalam konteks tertentu.

\section{Pengukuran Usabilitas}

Bagaimanapun juga mengukur kualitas perangkat lunak memang bukan pekerjaan mudah karena karena bersifat subyektif. Menurut Romy Satriyo (2006) sudut pandang seseorang tersebut mungkin berorientasi ke satu sisi masalah (misalnya tentang reliabilitas dan efisiensi perangkat lunak), sedangkan orang lain yang menyatakan bahwa perangkat lunak itu buruk menggunakan sudut pandang yang lain lagi (usabilitas dan aspek desain). Menurut Eko Nugroho (2009), kajian tentang usabilitas (kegunaan) merupakan bagian dari bidang ilmu multi disiplin Human Computer Interaction (HCI). Human Computer Interaction merupakan bidang ilmu yang berkembang sejak sekitar tahun 1970 yang mempelajari bagaimana mendesain tampilan layar komputer dalam suatu aplikasi sistem informasi agar nyaman dipergunakan oleh pengguna. Pendapat lain dikemukakan oleh Sunu Wibirama (2016) yang menyatakan bahwa usabilitas adalah sebuah bidang ilmu yang unik. Ilmu ini mempelajari bagaimana sebuah produk yang beroperasi di atas komputer (bisa berupa perangkat lunak, halaman web, atau disain sebuah package tertentu) dapat digunakan oleh konsumen tanpa harus berpikir panjang.

Penelitian ini menggunakan penilaian kualitas perangkat lunak ISO 9126-11. Model penilaian usabilitas tersebut di ilustrasikan oleh Bevan (1995) seperti tampak dalam Gambar 1.

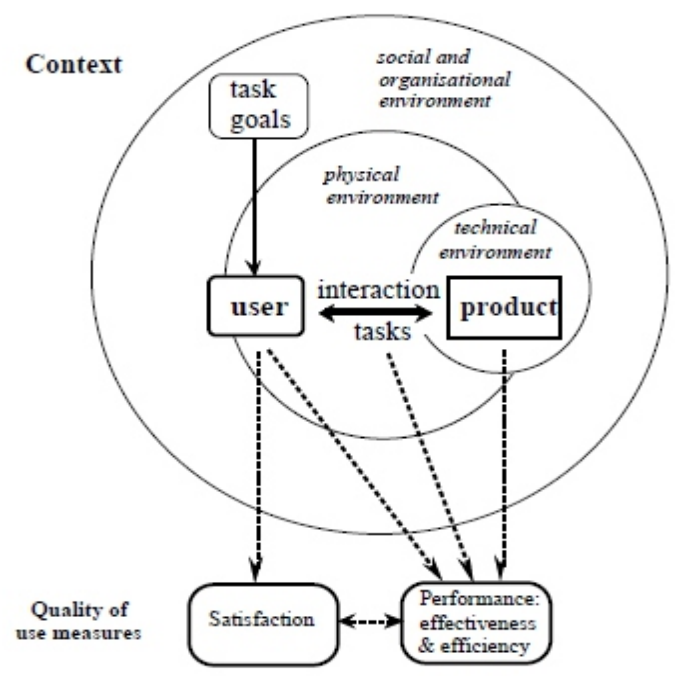

Gambar 1 Skema Pengukuran Usabilitas Penggunaan Produk. Sumber: Bevan (1995)

\section{Komponen Usabilitas}

Menurut ISO 9241-11 (1998) terdapat 3 dimensi yaitu efektivitas, efisiensi dan kepuasan yang diuraikan sebagai berikut:

1. Efektivitas: seberapa besar alat atau produk dapat membantu pengguna dalam menyelesaikan tugas-tugasnya.

2. Efisiensi: tingkat efektivitas yang dicapai, yang berkaitan dengan resource atau 
sumber daya. Sumber daya yang relevan dapat mencakup usaha mental atau fisik, waktu, dan biaya. Misalnya efisiensi manusia bisa diukur sebagai efektivitas dibagi dengan usaha manusia, efisiensi dan efektivitas temporal dibagi waktu, atau efisiensi ekonomi dibagi dengan biaya.

3. Kepuasan: mengukur sejauh mana pengguna bebas dari ketidaknyamanan dan sikap mereka terhadap penggunaan produk. Kepuasan bisa ditentukan dan diukur menurut penilaian subjektif pada skala seperti ketidaknyamanan yang dialami, kesukaan pada produk, kepuasan menggunakan produk, atau penerimaan dari beban kerja ketika melaksanakan tugas yang berbeda, atau sejauh mana tujuan kegunaan tertentu (seperti efisiensi atau learnability) telah dipenuhi.

\section{B. METODE PENELITIAN}

\section{Objek dan Waktu Penelitian}

Objek penelitian ini adalah Sistem Informasi Perpustakaan (SIPUS) Integrasi UGM yang digunakan di Perpustakaan Pusat dan 14 perpustakaan fakultas. Waktu penelitian direncanakan mulai 1 Juni hingga 15 Agustus 2016.

\section{Metodologi Penelitian}

Jenis penelitian ini adalah deskriptif kuantitatif yaitu data yang dikumpulkan selama penelitian dianalisis sesuai dengan metode statistik yang digunakan kemudian diinterprestasikan. Adapun langkahlangkahpenelitian ini yang dilalui ditunjukan dalam Gambar 2 berikut:

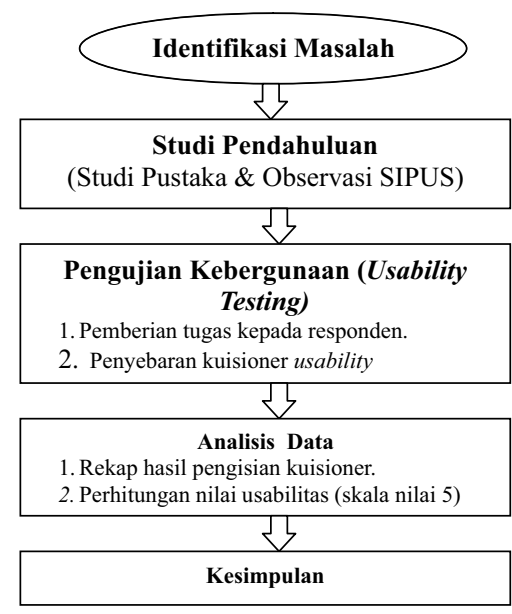

Gambar 2 Langkah Penelitian SIPUS

\section{Populasi dan Sampel Penelitian}

Populasi dalam penelitian ini yakni Pustakawan UGM. Sampel yang digunakan sebanyak 30 orang yang diambil melalui berbagai pertimbangan seperti: tingkat pendidikan, keahlian yang dimilikinya serta terwakilinya semua perpustakaan fakultas, pusat, sekolah vokasi dan sekolah kelas Jakarta.

\section{Teknik Pengumpulan Data}

Pengumpulan data dilakukan dengan cara melakukan survei langsung secara langsung melalui tatap muka, telepon dan email kepada semua responden yaitu pustakawan dan staf perpustakaan sebagai pengguna SIPUS Integrasi yang ada di berbagai perpustakaan di UGM.

Untuk mengumpulkan data digunakan seperangkat alat berupa angket / kuisioner yang berisi pertanyaan dan jawaban sesuai dengan penilaian responden. Guna mendapatkan tingkatan hasil pernilaian penggunaan Sipus Integrasi digunakan model gradasi penilaian dari responden menggunakan skala Likert. Responden akan melakukan penilaian terhadap semua pernyataan dalam pertanyaan kuesioner sesuai dengan penilaian mereka. Adapun tingkat penilaian terhadap pertanyaan yang diajukan adalah sebagai berikut:

1. Sangat Tidak Setuju (STS) mendapat skor 1.

2. Tidak Setuju (TS) mendapat skor 2.

3. Netral $(\mathrm{N})$ mendapat skor 3 .

4. Setuju (S) mendapat skor 4.

5. Sangat Setuju (SS) mendapat skor 5.

\section{Instrumen Penelitian}

Instrumen penelitian disusun berdasarkan variabel-variabel yang digunakan dalam penelitian ini, yaitu variabel bebas: Variabel effectiviness, efficiency dan satisfaction, serta variabel terikat usabilitas.

Adapun butir-butir pernyataan dalam penelitian ini adalah sebagai berikut:

1. Variabel Usabilitas: didefinisikan sebagai kegunaan atau manfaat produk.

Apakah Sipus Integrasi bermanfaat bagi perpustakaan yang saya kelola?

2. Variabel Efektivitas: seberapa baik pengguna mencapai tujuan mereka dengan menggunakan SIPUS dala m menyelesaikan pekerjaan yang mereka lakukan. 
[1.] Apakah SIPUS membantu pekerjaan dalam transaksi sirkulasi buku?

[2.] Apakah SIPUS membantu pekerjaan dalam pengolahan bahan pustaka buku?

[3.] Apakah SIPUS membantu dalam memperoleh laporan / statistik pekerjaan?

3. Variabel Efisiensi: didefinisikan sebagai sumberdaya yang dikeluarkan guna mencapai ketepatan dan kelengkapan tujuan.

[1.] Apakah SIPUS membantu menghemat waktu dalam menyelesaikan pekerjaan perpustakaan?

[2.] Apakah SIPUS membantu menghemat tenaga / sumberdaya dalam menyelesaikan pekerjaan perpustakaan?

[3.] Apakah SIPUS membantu menghemat biaya dalam menyelesaikan pekerjaan perpustakaan?

[4.] Apakah SIPUS membantu saya dalam mengambil keputusan dengan cepat?

4. Variabel kepuasan diartikan sebagai kebebasan dari ketidaknyamanan, dan sikap positif terhadap pemakaian produk atau ukuran subjektif bagaimana pengguna merasa tentang penggunaan SIPUS.

[1.] Apakah operasional SIPUS mudah dan memuaskan?

[2.] Apakah laporan / statistik dalam SIPUS dapat memuaskan dalam mendapatkan informasi yang dibutuhkan?

5. Saran Anda untuk perbaikan SIPUS Integrasi?

\section{Analisis Data}

Analisis data penelitian ini menggunakan Analisis Regresi Ganda. Analisis data bertujuan untuk menguji pola hubungan tiga variabel independen dan satu variabel dependen. Untuk membantu analisa data, peneliti menggunakan software SmartPLS3 (Partial Least Square). Partial Least Square merupakan metode analisis yang berbasis variance atau Component Based SEM. Structural equation modeling (SEM) adalah analisis faktor (factor analysis), analisis jalur (path analysis) dan regresi (regression).

\section{HASIL DAN PEMBAHASAN}

Dalam penelitian ini peneliti menyebarkan banyak kuesioner untuk dijadikan sampel atau responden dari pustakawan dan tenaga perpustakan di berbagai perpustakaan di UGM. Dari 40 kuesioner peneliti menetapkan 30 responden yang telah mengisi data yang lengkap dan layak dijadikan sampel atau responden dalam penelitian ini. Responden merupakan staf perpustakaan yang dalam keseharianya aktif mengoperasikan atau menggunakan SIPUS Integrasi dalam pekerjaanya.

Berdasarkan kategori jenis kelamin maka gambaran responden ditunjukan pada Gambar 3 berikut:

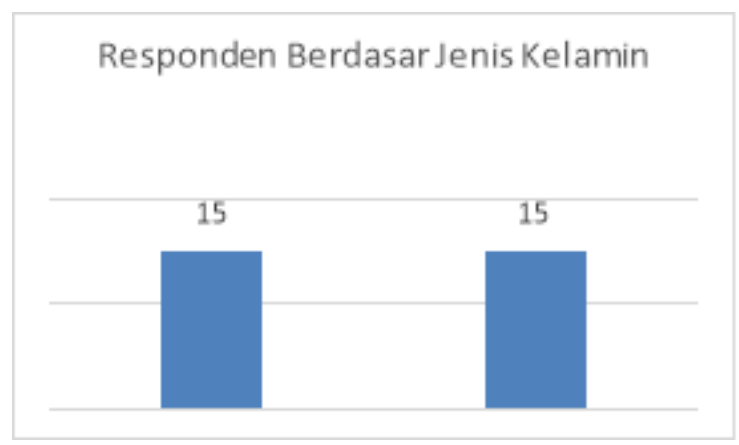

Gambar 3 Grafik Responden Berdasarkan Jenis Kelamin

Berdasarkan tingkat pendidikan responden maka gambaran responden ditunjukan pada Gambar 4 berikut:

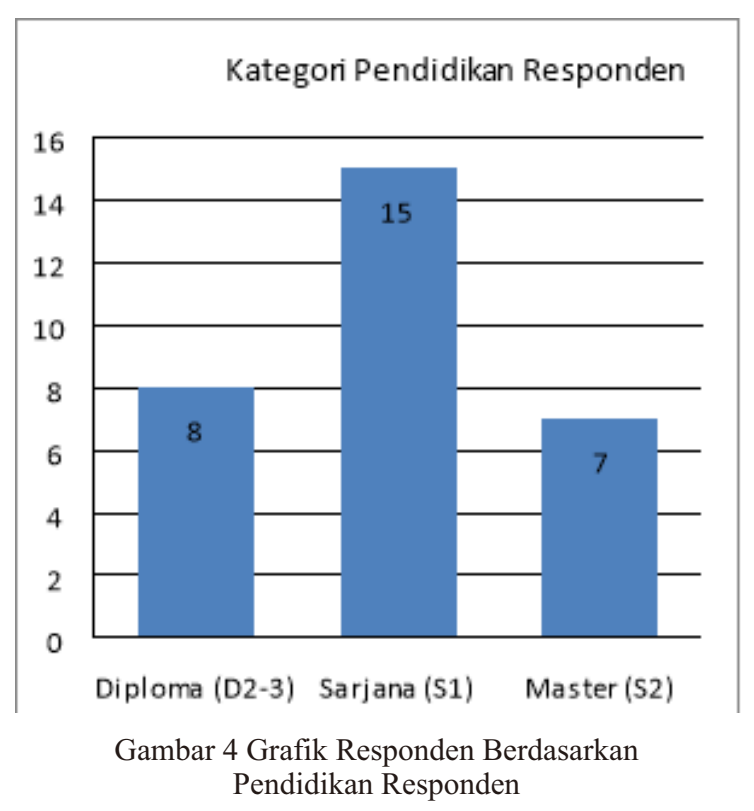




\section{Uji Reliabilitas}

Uji reliabilitas digunakan untuk test dari hipotesis yang sudah dibuat pada tahap awal penelitian harus dilihat keandalannya. Suatu instrumen dapat dikatakan andal bilamana instrumen tersebut menghasilkan hasil yang konsisten apabila instrumen tersebut dipergunakan secara berulang memberikan hasil ukur yang sama.
Dalam penelitian ini, uji keandalan setiap variabeld iukur dengan menggunakan Cronbach's alpha. Alasan peneliti menggunakan uji Cronbach's alpha antara lain karena teknik pengujian keandalan kuesioner ini merupakan metode yang sering digunakan dan metode ini memudahkan mendeteksi indikator-indikator yang tidak konsisten. Dari hasil oleh data dengan software Smart PLS3 dihasilkan data seperti dalam Gambar 5 berikut:

\section{Construct Reliability and Validity}

\begin{tabular}{|c|c|c|c|c|c|c|c|}
\hline \multirow[t]{2}{*}{ Matrix } & \multirow[t]{2}{*}{ 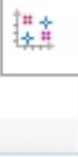 } & Cronbach's Alpha & 掉音 rho_A & \multicolumn{2}{|c|}{ 接謀 Composite Reliability } & \multicolumn{2}{|r|}{ 㩰蛒 Average Variance Extracted ... } \\
\hline & & Cronbach's Alpha & & rho_A & Composite Reliabil & & Average Variance Extracted (AVE) \\
\hline Efektifitas & & 0.729 & & 0.764 & 0.8 & & 0.649 \\
\hline Efisien & & 0.868 & & 0.947 & 0.91 & & 0.720 \\
\hline Kepuasan & & 0.761 & & 1.173 & 0.87 & & 0.784 \\
\hline Usabilitas SI & PUS_ & 1.000 & & 1.000 & 1.00 & & 1.000 \\
\hline
\end{tabular}

Gambar 5 Reliabilitas \& Validitas Konstruk

Nilai tingkat keandalan Cronbach's Alpha menurut Hair et al. (2010: 125) ditunjukan pada Tabel 1 berikut:

Tabel 1 Tingkat Keandalan Konstruk

\begin{tabular}{|c|c|}
\hline $\begin{array}{c}\text { Nilai Cronbach's } \\
\text { Alpha }\end{array}$ & $\begin{array}{c}\text { Tingkat } \\
\text { Keandalan }\end{array}$ \\
\hline $0.0-0.20$ & Kurang Andal \\
\hline$>0.20-0.40$ & Agak Andal \\
\hline$>0.40-0.60$ & Cukup Andal \\
\hline$>0.60-0.80$ & Andal \\
\hline$>0.80-1.00$ & Sangat Andal \\
\hline
\end{tabular}

Melihat data dari 2 tabel diatas dapat dikatakan bahwa variabel yang digunakan dalam penelitian masuk dalam kategori reliabilitas yang andal.

\section{Uji Validitas}

Uji validitas dilakukan untuk memastikan seberapa baik suatu instrumen digunakan untuk mengukur konsep yang seharusnya diukur suatu indikator dinyatakan valid jika mempunyai loading factor di atas 0,5 terhadap konstruk yang dituju. Luaran dari perhitungan dari SmartPLS3 untuk loading factor memberikan hasil seperti ditunjukan Gambar 6 berikut:

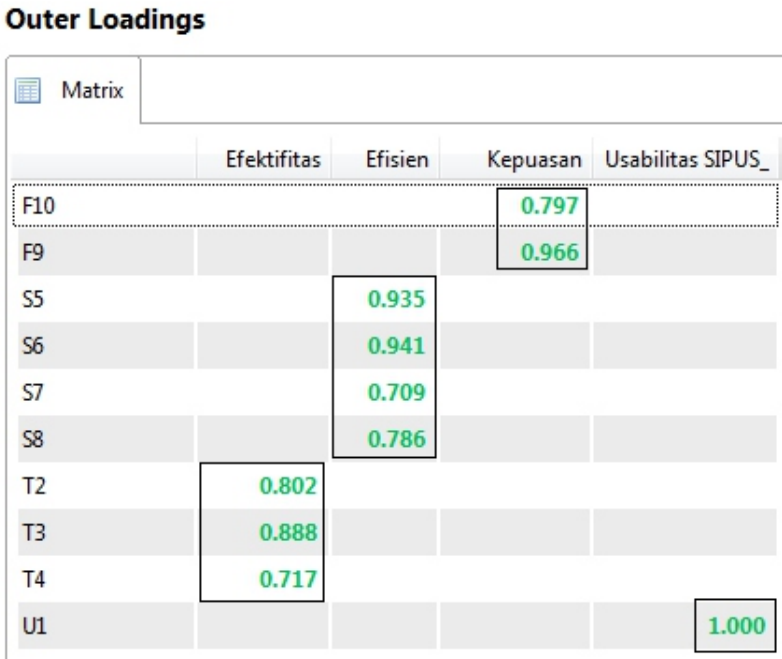

Gambar 6 Outer Loadings Usabilitas Sipus

Dari hasil perhitungan diatas menunjukan bahwa Indikator tingkat validitas dapat dilihat apabila outer loading factor menunjukkan nilai di atas 0,70. Dari Gambar 4.2 Outer Factor masing-masing indikator di atas batas yang ditentukan sehingga semua konstruk telah memenuhi convergent validity yang tinggi. 
Tanggapan Responden Atas Variabel Penilaian

Pembahasan terhadap hasil tanggapan responden atas variabel penelitian terdiri atas 4 hal yaitu usabilitas, efektivifitas, efisiensi dan kepuasan. Untuk menginterpretasikan jawaban responden atas variabel pernyataan, setiap jawaban akan dikonversikan dalam suatu interval penilaian. Semakin tinggi angka dalam suatu interval maka akan mendapatkan kategori peniliaian yang tinggi.

Guna menilai nilai rata-rata jawaban responden terhadap masing-masing item pernyataan setiap variabel selanjutnya disusun suatu interval kelas dengan rumusan seperti berikut:

$$
\begin{aligned}
\text { Interval kelas } & =\frac{\text { Nilai Tertinggi }- \text { Nilai Terendah }}{\text { Jumlah kelas }} \\
& =\frac{5-1}{5}=0.8
\end{aligned}
$$

Dari hitungan di atas didapatkan interval kelas sebesar 0.8. Dengan interval kelas 0.8 kemudian disusun kategori penilaian dari rerata jawaban responden seperti yang disajikan pada Tabel 2 di bawah ini:

Tabel 2 Kategorisasi Penilaian

\begin{tabular}{|l|c|l|}
\hline \multicolumn{1}{|c|}{ Jawaban } & \multicolumn{1}{c|}{ Interval } & \multicolumn{1}{c|}{ Kategori } \\
\hline Sangat Setuju & $4.21<\mathrm{a}=<5.00$ & Sangat Tinggi \\
\hline Setuju & $3.41<1=<4.20$ & Tinggi \\
\hline Netral & $2.61<\mathrm{a}=<3.40$ & Cukup \\
\hline Tidak Setuju & $1.81<\mathrm{a}=<2.60$ & Rendah \\
\hline Sangat Tidak Setuju & $1.00<\mathrm{a}=<180$ & Sangat Rendah \\
\hline
\end{tabular}

\section{Analisis Variabel $U$ sabilitas}

Berdasarkan nilai rata-rata jawaban responden atas variabel usabilitas SIPUS Integrasi diperoleh nilai rata-rata sebesar $\mathbf{4 . 3 3}$ yang berarti bahwa responden menyatakan sangat setuju atas pernyataan SIPUS Integrasi bermanfaat dalam proses perpustakaan tempat mereka bekerja. Dengan hasil ini tingkat penilaian responden terhadap usabilitas Sipus Integrasi masuk dalam kategori Sangat Tinggi seperti ditunjukan dalam Tabel 3.

\section{Analisis Variabel Efektifitas}

Berdasarkan perhitungan nilai rata-rata jawaban dari 3 pernyataanatas variabel efektifitas sebesar $\mathbf{4 . 1 5}$ menunjukan bahwa responden menyatakan setuju jika SIPUS Integrasi efektif digunakan sebagai sistem informasi perpustakaan di tempat kerja. Hasil ini mengukuhkan penilaian responden terhadap tingkat efektifitas SIPUS Integrasi digunakan di tempat mereka bekerja masuk dalam kategori tinggi seperti ditunjukan dalam tabel 4 .

\section{Analisis Variabel Efisiensi \\ Berdasarkan perhitungan nilai rata-rata jawaban dari 4 pernyataan atas variabel efisiensi sebesar 3.95 menunjukan bahwa responden menyatakan setuju jika situs SIPUS Integrasi efisien digunakan sebagai sistem informasi perpustakaan di tempat merka bekerja. Hasil ini mengukuhkan penilaian responden terhadap tingkat efisiensi SIPUS Integrasi digunakan di perpustakaan masuk dalam kategori tinggi seperti ditunjukan dalam Tabel 5.}

Tabel 3 Tanggapan responden atas variabel Usabilitas Sipus

\begin{tabular}{|c|l|c|c|c|c|c|c|c|}
\hline \multirow{2}{*}{ No } & \multicolumn{1}{|c|}{ Indikator } & \multicolumn{5}{c|}{ Frekuensi Skor Jawaban } & \multirow{2}{*}{ Rerata } & \multirow{2}{*}{ Kategori } \\
\cline { 3 - 8 } & \multicolumn{1}{|c|}{1} & 2 & 3 & 4 & 5 & \\
\hline 1 & $\begin{array}{l}\text { Sipus Integrasi bermanfaat dalam } \\
\text { proses bisnis perpustakaan yang } \\
\text { Bapak/Ibu kelola }\end{array}$ & 0 & 0 & 0 & 80 & 50 & 4.333 & $\begin{array}{l}\text { Sangat } \\
\text { Tinggi }\end{array}$ \\
\hline
\end{tabular}

\begin{tabular}{|c|c|c|c|c|c|c|c|c|}
\hline \multirow{2}{*}{ No } & \multirow{2}{*}{ Indikator } & \multicolumn{5}{|c|}{ Frekuensi Skor Jawaban } & \multirow{2}{*}{ Rerata } & \multirow{2}{*}{ Kategori } \\
\hline & & 1 & 2 & 3 & 4 & 5 & & \\
\hline 1 & $\begin{array}{l}\text { Sipus memudahkan proses sirkulasi } \\
\text { buku di perpustakaan }\end{array}$ & 0 & 0 & 1 & 19 & 10 & 4.30 & Tinggi \\
\hline 2 & $\begin{array}{l}\text { Sipus memudahkan proses pengolahan } \\
\text { bahan pustaka }\end{array}$ & 0 & 0 & 2 & 19 & 9 & 4.23 & Tinggi \\
\hline 3 & $\begin{array}{l}\text { Sipus memudahkan mendapatkan } \\
\text { informasi (laporan / statistik) }\end{array}$ & 0 & 2 & 7 & 14 & 7 & 3.93 & Tinggi \\
\hline \multicolumn{7}{|c|}{ Rata-rata } & 4.15 & Tinggi \\
\hline
\end{tabular}

Tabel 4 Tanggapan Responden atasVariabel Efektifitas Sipus 
Tabel 5 Tanggapan Responden atasVariabel Efisiensi Sipus

\begin{tabular}{|c|c|c|c|c|c|c|c|c|}
\hline \multirow{2}{*}{ No } & \multirow{2}{*}{ Indikator } & \multicolumn{5}{|c|}{ Frekuensi Skor Jawaban } & \multirow{2}{*}{ Rerata } & \multirow{2}{*}{ Kategori } \\
\hline & & 1 & 2 & 3 & 4 & 5 & & \\
\hline 1 & $\begin{array}{l}\text { Sipus Integrasi menghemat tenaga } \\
\text { dalam menyelesaikan pekerjaan }\end{array}$ & 0 & 1 & 5 & 14 & 10 & 4.10 & Tinggi \\
\hline 2 & $\begin{array}{l}\text { Sipus menghemat tenaga dalam } \\
\text { menyelesaikan pekerjaan }\end{array}$ & 0 & 1 & 5 & 19 & 5 & 3.96 & Tinggi \\
\hline 3 & $\begin{array}{l}\text { Sipus menghemat biaya dalam } \\
\text { menyelesaikan pekerjaan }\end{array}$ & 0 & 0 & 7 & 18 & 5 & 3.93 & Tinggi \\
\hline 4 & $\begin{array}{l}\text { Sipus membantu dalam mengambil } \\
\text { keputusan }\end{array}$ & 0 & 1 & 7 & 18 & 4 & 3.83 & Tinggi \\
\hline \multicolumn{7}{|c|}{ Rata-rata } & 3.95 & Tinggi \\
\hline
\end{tabular}

Tabel 6 Tanggapan Responden atas Variabel Kepuasan

\begin{tabular}{|c|c|c|c|c|c|c|c|c|}
\hline \multirow{2}{*}{ No } & \multirow{2}{*}{ Indikator } & \multicolumn{5}{|c|}{ Frekuensi Skor Jawaban } & \multirow{2}{*}{ Rerata } & \multirow{2}{*}{ Kategori } \\
\hline & & 1 & 2 & 3 & 4 & 5 & & \\
\hline 1 & $\begin{array}{l}\text { Operasional Sipus sesuai dengan } \\
\text { keinginan saya }\end{array}$ & 0 & 2 & 7 & 19 & 2 & 3.70 & Tinggi \\
\hline 2 & $\begin{array}{l}\text { Laporan \& statistik Sipus sesuai dengan } \\
\text { keinginan saya }\end{array}$ & 0 & 2 & 11 & 12 & 5 & 3.56 & Tinggi \\
\hline \multicolumn{7}{|c|}{ 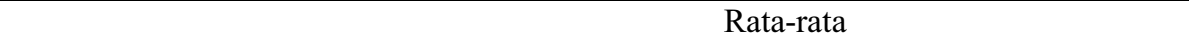 } & 3.63 & Tinggi \\
\hline
\end{tabular}

\section{Analisis Variabel Kepuasan}

Berdasarkan perhitungan nilai rata-rata jawaban 2 pernyataan dari variabel kepuasan dalam menggunakan SIPUS Integrasi dihasilkan nilai rata-rata sebesar 3.63. Nilai 3.63 menunjukan bahwa responden menyatakan setuju atas pernyataan dalam variabel kepuasan menggunakan SIPUS Integrasi. Hasil ini mengukuhkan penilaian responden terhadap tingkat kepuasan dalam menggunakan SIPUS Integrasi masuk dalam kategori tinggi seperti ditunjukan dalam Tabel 6.

\section{Identifikasi Kekurangan SIPUS}

Meskipun hasil penelitian tingkat usabilitas Sipus Integrasi mendapat penilaian yang tinggi namun demikian ada berbagai catatan untuk perbaikan dari sistem ini dari para responden dan peneliti yang harus dibenahi baik dari segi teknis maupun non-teknis. Adapun kekurangan antara lain adalah, sebagai berikut:

1. Laporan dan statistik kolom data yang ada tidak dapat menampilkan kategorisasi data di tingkat fakultas jumlah pengunjung setiap jurusan, program studi dan jenjang pendidikan (D3, S1,S2, S3).

2. Untuk mendapatkan data statistik diperlukan waktu yang lama, akses dalam fitur tersebut lambat.
3. Tidak ada daftar pengunjung yang bisa ditampilkan dalam fitur absensi pengunjung.

4. Aktifasi angota perpustakaan di luar fakultas pada beberapa kasus tidak bisa dilakukan.

5. Respon yang tidak cepat dari Tim Teknologi Informasi yang ada di Perpustakaan Pusat UGM dalam menangani berbagai keluhan dari perpustakaan pengguna sistem.

\section{E. PENUTUP}

\section{Kesimpulan}

Berdasarkan hasil analisis dan pembahasan yang telah dilakukan maka kesiimpulan dari penelitian adalah sebagai berikut:

1. Tingkat usabilitas penggunaan SIPUS Integrasi di berbagai perpustakaan UGM masuk dalam kategori sangat tinggi.

2. Tingkat efektifitas penggunaan SIPUS Integrasi di berbagai perpustakaan UGM masuk dalam kategori tinggi.

3. Tingkat efisiensi penggunaan SIPUS Integrasi di berbagai perpustakaan UGM masuk dalam kategori tinggi.

4. Adanya pengaruh signifikan antara variabel-variabel efektifitas, efisiensi dan 
kepuasan terhadap variabel usabilitas. Hal ini menunjukan tingkat usabilitas SIPUS Integrasi yang sangat tinggi di berbagai perpustakaan di UGM.

\section{Saran}

Dari hasil penelitian dan survei yang dilakukan di beberapa perpustakaan yang peneliti kunjungi banyak saran yang diberikan untuk perbaikan SIPUS Integrasi ke depannya saran-saran tersebut antara lain adalah:

- Perlunya penelitian lanjutan yang membahas sisi teknis SIPUS Integrasi sehingga bisa diketahui berbagai kelemahan teknis yang ada.

- Untuk kesempurnaan sistem perlu perbaikan dari fitur-fitur laporan dan statistik yang dapat disesuaikan dengan kebutuhan perpustakaan yang ada di tingkat fakultas.

- Perlu respon yang cepat bagi Tim Teknologi Informasi yang ada di Perpustakaan Pusat UGM dalam menangani berbagai keluhan dari perpustakaan pengguna sistem.

\section{DAFTAR PUSTAKA}

Bevan, N., 1995. Measuring usability as quality of use. Software Quality Journal, 4(2), pp.115-130.

Dumas, Joseph S. (1999). A Practical Guide to Usability Testing. Intellect Books, Oregon USA.

Hair, J. F., Anderson, R. E., Tatham, R. L., \& Black, W. C., 1998. Multivariate Data Analysis, fifth edition. New Jersey: Prentice-Hall International, Inc.

Jeff Axup., Viller S, \&Bidwell, N. (2005) Usability of aMobile, Group Communication Prototype While Rendezvousing. CTS'05 International Sysmposium on Collaborative TEchnolgies and System. May 15-20, Louis, Mo, USA.

International Organization for Standardization, (1998), ISO 9241-11: Guidance on Usabilitas. https://www.iso.org/ obp/ui/\#iso:std:iso:9241:-11:dis:ed2:v1:en. Akses April 2016

Nugroho, Eko. 2008. Sistem Informasi Manajemen: Konsep, Aplikasi \& Perkembangannya. Yogyakarta: Andi Offset.

Rubin, Jeffrey \& Chisnell, Dana 2008. Handbook of Usability Testing: How to Plan, Design, and Conduct Effective Tests. Wiley Publishing, Inc. Indianapilis. Indiana, USA.

Satriyo, Romi. (2006). Teknik Pengukuran Kualitas Perangkat Lunak. Posted by Romi Satria Wahono on 5 Jun, 2006 in Software Engineering. http://romisatriawahono.net/ 2006/06/05/teknik-pengukuran-kualitasperangkat-lunak/Akses 5 Agustus 2016.

Sugiyono.2009. Metode Penelitian Kuantitatif Kualitatif dan $R \& D$. Bandung: Alfabeta

Weber, D.O. (1999): Web Sites of Tomorrow: How the Internet will transform health. Health Forum Journal, May-June, 40-45

Wibirama, Sunu, ( 2016$)$. Usability. http://sunu.staff.ugm.ac.id/usability/ Akses: 5-8-2016 